\title{
Cardiac biomarkers as sensitive tools to evaluate the impact of xenobiotics on amphibians: the effects of anionic surfactant linear alkylbenzene sulfonate (LAS)
}

\author{
Monica Jones-Costa ${ }^{\mathrm{a}}$, Lilian Franco-Belussi ${ }^{\mathrm{a}, \mathrm{b}, \mathrm{c}}$, Felipe Augusto Pinto Vidal ${ }^{\mathrm{a}, \mathrm{b}}$, \\ Nathália Penteado Gongora ${ }^{\mathrm{a}}$, Luciano Mendes Castanho ${ }^{\mathrm{a}}$, Cleoni dos Santos Carvalho ${ }^{\mathrm{a}}$, \\ Elaine Cristina Mathias Silva-Zacarin ${ }^{\mathrm{d}}$, Fabio Camargo Abdalla ${ }^{\mathrm{e}}$, Iolanda Cristina Silveira Duarte $\mathrm{f}^{\mathrm{f}}$ \\ Classius De Oliveira ${ }^{c}$, Cristiane Ronchi de Oliveira ${ }^{c}$, Raquel Fernanda Salla ${ }^{a, *}$ \\ ${ }^{a}$ Laboratório de Fisiologia da Conservação, Universidade Federal de São Carlos, Rodovia João Leme dos Santos (SP-264), Km 110, Bairro do Itinga, Sorocaba, São Paulo \\ 18052-780, Brazil

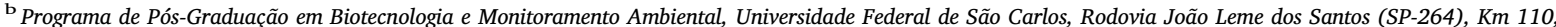 \\ Bairro do Itinga, Sorocaba, São Paulo 18052-780, Brazil \\ ${ }^{\mathrm{c}}$ Departamento de Biologia, Universidade Estadual Paulista (UNESP), 15054-000 São José do Rio Preto, São Paulo, Brazil \\ d Núcleo de Pesquisa em Ecotoxicologia de Abelhas, Universidade Federal de São Carlos, Rodovia João Leme dos Santos (SP-264), Km 110, Bairro do Itinga, Sorocaba, \\ São Paulo 18052-780, Brazil

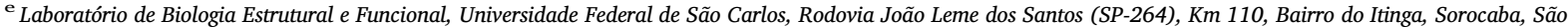 \\ Paulo 18052-780, Brazil \\ ${ }^{\mathrm{f}}$ Laboratório de Microbiologia Ambiental (LaMA), Universidade Federal de São Carlos, Rodovia João Leme dos Santos (SP-264), Km 110, Bairro do Itinga, Sorocaba, São \\ Paulo 18052-780, Brazil
}

\section{A R T I C L E I N F O}

\section{Keywords:}

Pollutant

Heart

Anurans

Cardiac function, ecotoxicology

\begin{abstract}
A B S T R A C T
Amphibian populations have been experiencing a drastic decline worldwide. Aquatic contaminants are among the main factors responsible for this decline, especially in the aquatic environment. The linear alkylbenzene sulfonate (LAS) is of particular concern, since it represents $84 \%$ of the anionic surfactants' trade. In Brazil, the maximal LAS concentration allowed in fresh waters is $0.5 \mathrm{mg} \mathrm{L}^{-1}$, but its potential harmful effects in amphibians remain unknown. Therefore, this study aimed to analyze the effects of a sublethal concentration of LAS $\left(0.5 \mathrm{mg} \mathrm{L}^{-1}\right)$ for $96 \mathrm{~h}$ on sensitive cardiac biomarkers of bullfrog tadpoles, Lithobates catesbeianus (Shaw, 1802). For this, we measured the activity level (AL - \% of animals), in situ heart rate $\left(f_{\mathrm{H}}-\mathrm{bpm}\right)$, relative ventricular mass (RVM - \% of body mass), in vitro myocardial contractility and cardiac histology of the ventricles. Tadpoles' AL and $f_{\mathrm{H}}$ decreased in LAS group. In contrast, the RVM increased, as a result of a hypertrophy of the myocardium, which was corroborated by the enlargement of the nuclear measures and the increase of myocytes' diameters. These cellular effects resulted in an elevation of the in vitro contractile force of ventricle strips. Acceleration in the contraction (TPT - ms) also occurred, although no alterations in the time to relaxation (THR -ms) were observed. Therefore, it can be concluded that even when exposed to an environmentally safe concentration, this surfactant promotes several alterations in the cardiac function of bullfrog tadpoles that can impair their development, making them more susceptible to predators and less competitive in terms of reproduction success. Thus, LAS concentrations that are considered safe by Brazilian by regulatory agencies must be revised in order to minimize a drastic impact over amphibian populations. This study demonstrates the relevance of employing cardiac biomarkers at different levels (e.g., morphological, physiological and cellular) to evaluate effects of xenobiotics in tadpoles.
\end{abstract}

\section{Introduction}

Amphibians have long suffered from a serious decline in their populations (Collins and Storfer, 2003; Wake and Vredenburg, 2008; Collins, 2010;). These declines occur in different regions of the world and result from various different factors such as the loss and

\footnotetext{
* Correspondence to: Rodovia João Leme dos Santos (SP-264), Km 110, Bairro do Itinga, Sorocaba, São Paulo 18052-780, Brazil.

E-mail addresses: lilian.belussi@gmail.com (L. Franco-Belussi), classius@ibilce.unesp.br (C.D. Oliveira), raquelsalla@hotmail.com (R.F. Salla).
} 
fragmentation of their habitats, increased ultraviolet radiation, global warming, emerging infectious diseases and the presence of contaminants, notably those in aquatic environments (Blaustein et al., 1994; Collins and Storfer, 2003; Roe et al., 2005; Collins, 2010; Hof et al., 2011; Abdalla et al., 2013; Van Meter et al., 2014; Costa et al., 2015, 2016; Carvalho et al., 2017). Indeed, several studies have provided evidence that aquatic contaminants are among the main causes of amphibian declines (Collins, 2010; Blaustein et al., 2011). Acting alone or combined in the environment, the contaminants can cause changes ranging from cellular and physiological to ecological and population (Collins, 2010).

In order to maximize cutaneous respiration and osmotic balance mechanisms, amphibians present a particularly thin and highly permeable skin (Heatwole and Wilkinson, 2009). This makes them especially susceptible to xenobiotics due to the lack of a hydrophobic barrier and its high porosity to water molecules (Van Meter et al., 2014). Tadpoles, in turn, are even more susceptible to contaminants as they are born and develop in superficial waters, have highly permeable skin and undergo complex morpho-physiological changes controlled by many hormonal pathways (Shi, 2000). Tadpoles can also be exposed to contaminants through either food (Sparling et al., 2000) or gills (BuenoGuimarães et al., 2001), but to a lesser extent. Moreover, as in most other ectothermic vertebrates, the metabolism of anuran larvae is relatively lower than that observed in avians and mammals (McDiarmid and Altig, 1999). As a consequence, lower catabolism and depuration rates are also observed in these animals when compared with birds and mammals, which increases the bioaccumulation of xenobiotics (Lillywhite et al., 1999).

In this context, it is worth emphasizing the participation of surfactants as potential pollutants. These compounds are widely used in washing products and cosmetic products (Ivankovi and Hrenović, 2010) such as emulsifying agents and foaming promoters (Brasil, 2014). They are classified as anionic, cationic and nonionic according to the load of its hydrophilic head (Penteado et al., 2006). In 2012, anionic surfactants represented $28 \%$ of the detergent's global market, with growth prospects of $2.5 \%$ by the year 2020 (Brasil, 2014). Linear alkylbenzene sulfonate (LAS) represents $84 \%$ of the anionic market. Brazil's participation in the surfactant market reached 1.5 billion dollars with a growth of 7\% per year between 2009 and 2012 and growth prospects of around 2.1 billion dollars by 2018 (Brasil, 2014).

It is important to mention that the maximum LAS concentration allowed for fresh waters in Brazil is $2.5 \mathrm{mg} \mathrm{L}^{-1}$. However, after its usage, the entire range of products containing LAS is discharged into sewers, and consequently reaches the environment (Ivankovi and Hrenović, 2010).

In the aquatic environment, LAS is known to damage fish gills and cause excessive mucus secretion (Venhuis and Mehrvar, 2004). Although there is strong evidence that LAS is taken up via gills rather than the skin in fish (Kikuchi et al., 1980; Tolls et al., 1994), it has been demonstrated that surfactants lead to marked alterations in the skin morphology of amphibians, causing hyperplasia or hypertrophy of the epithelium (Rissoli et al., 2016). Another alteration of LAS in fish is related to increasing liver vacuolization (Priya et al., 2016) and scattering inflammation (Kumar et al., 2007).

Regarding the effects of LAS on $\mathrm{Ca}^{2+}$ homeostasis, a decay in the electrophysiological potential of the abdominal skin in Rana pipiens was observed (Kulkarni and Goddard, 1980). Additionally, LAS induces an increase in intracellular $\mathrm{Ca}^{2+}$ concentration in cultured epithelial cells of Xenopus laevis kidney tissues (Bjerregaard et al., 2001). Alterations in cellular membrane permeability by surfactants, which interferes with intracellular $\mathrm{Ca}^{2+}$ balance, were already reported for Xenopus laevis when exposed to the other surfactant (POEA - polyethoxylated tallow amine; Hedberg and Wallin, 2010). These observations are particularly relevant, especially with respect to the maintenance of mechanisms and physiological functions, notably the cardiac function, which directly requires refined calcium supply for the maintenance of contractile mechanisms. Cardiac function is directly related to various important functions such as oxygenation, circulation and distribution of nutrients, which, once unbalanced, can aggravate other directly dependent functions, such as growth and metamorphosis, metabolism, among other functions (Lillywhite et al., 1999).

Thus, considering the previous findings about the effects of LAS on $\mathrm{Ca}^{2+}$ management and the lack of studies analyzing the effects of surfactants on amphibians' physiology and morphology, this study aimed to evaluate the effects of exposure to a sublethal concentration of the surfactant LAS on cardiac biomarkers of bullfrog tadpoles. By recognizing the physiological responses to environmental contaminants, adaptive strategies of species can be identified in order to determine the survival of these organisms in their habitats. Cardiac biomarkers have been used as a determinant and quite a sensitive tool to detect responses of the organism to environmental changes (Dal-Medico et al., 2014; Salla et al., 2016). By using these biomarkers, more effective responses to environmental monitoring can be proposed.

\section{Material and methods}

\subsection{Animal care}

Ninety-six tadpoles (Lithobates catesbeianus, Shaw 1802) were acquired from a frog farm in São Roque, São Paulo State, Southeast Brazil $\left(22^{\circ} 78^{\prime} \mathrm{S}, 47^{\circ} 40^{\prime} \mathrm{W}\right)$. Tadpoles were placed in $60 \mathrm{~L}$ aquaria (i.e. closed system) equipped with a continuous supply of aerated $\left(1.2 \mathrm{~L} \mathrm{~h}^{-1}\right)$ and dechlorinated water at a constant temperature $\left(25 \pm 1{ }^{\circ} \mathrm{C}\right)$, and under natural photoperiod ( $\sim 12 \mathrm{~h}$ light/dark), until they reached Gosner developmental stage 25 (Gosner, 1960). The tadpoles were fed every two days with cooked organic lettuce ad libitum, which was stopped $48 \mathrm{~h}$ before exposure. All leftover food and feces remaining in the aquaria were removed. Only after reaching Gosner developmental stage 25 (Gosner, 1960), the ecotoxicological procedures were performed.

\subsection{Ecotoxicological experiments}

During the whole experimental period, water was monitored daily to ensure that the physical and chemical parameters were maintained at acceptable levels ( $\mathrm{pH}$ 7.5-7.6; hardness as $\mathrm{CaCO}_{3} 51-58 \mathrm{mg} \mathrm{L}^{-1}$; dissolved oxygen 7.0-7.5 $\mathrm{mg} \mathrm{L}^{-1}$; conductivity $97.56 \pm 0.02 \mu \mathrm{S} \mathrm{cm}^{-1}$ TDS Digital ${ }^{\circledR}$ ), similar to most Brazilian inland waters (CONAMA, 2011). Ammonia concentrations in water were checked every day (K1510;CHEMets) and remained under $1 \mathrm{mg} \mathrm{L}^{-1}$. All parameters were kept within acceptable (ASTM, 2014) guidelines.

For the exposure procedures, tadpoles $(\mathrm{N}=72)$ with body mass between 2.39 and $3.37 \mathrm{~g}(2.81 \pm 0.17 \mathrm{~g}-$ mean $\pm \mathrm{SE})$, were randomly divided into two experimental groups (triplicated): controls (CT; $\mathrm{N}=$ 12 each aquarium), and LAS-exposed at the sublethal concentration of $0.5 \mathrm{mg} \mathrm{L}^{-1}$ for $96 \mathrm{~h}$ (LAS; $\mathrm{N}=12$ each) in a static-system. To date, there are no studies of lethal doses of this contaminant in amphibian populations, therefore the concentration used was based on the reference values of $\mathrm{LC}_{50}$ of LAS for fish (Coelho and Rocha, 2010). Moreover, the maximum LAS concentration allowed in Brazilian fresh waters is $0.5 \mathrm{mg} \mathrm{L}^{-1}$ (CONAMA, 2011). Thus, it is important to verify the possible consequences of such concentrations.

The anionic surfactant sodium dodecylbenzene sulfonate (LAS, linear formula $\mathrm{CH}_{3}\left(\mathrm{CH}_{2}\right)_{11} \mathrm{C}_{6} \mathrm{H}_{4} \mathrm{SO}_{3} \mathrm{Na}$; molecular weight: $348.48 \mathrm{~g}$ ), with $80 \%$ purity, was provided by Sigma Aldrich ${ }^{\circ}$. According to the Brazilian environmental council (CONAMA, 2011), this concentration is considered suitable for inland waters intended for recreational fishing, supply for humans (after treatment), livestock consumption and watering crops.

All experimental groups were placed in $12 \mathrm{~L}$ glass aquaria filled with dechlorinated and aerated water $\left(\geq 6.0 \mathrm{mg} \mathrm{O} \mathrm{O}_{2} . \mathrm{L}^{-1}\right)$ with controlled temperature $\left(25 \pm 1{ }^{\circ} \mathrm{C}\right)$ on a $12: 12 \mathrm{~h}$ light: dark cycle. The sides of the aquaria were covered with dark plastic to prevent external 
stressors. During the experiments the animals were not fed and the water was not changed in order to avoid handling stress. All procedures complied with ASTM (2014) guidelines and the experiments were approved by the University's Ethics Committee (Protocol\#022/2010), which follows Brazilian regulating laws.

From the first day after exposure until the last one, the activity level $(\mathrm{N}=36)$ of the tadpoles (CT and LAS groups) was monitored (twice a day), following the methodology described by Fraker and Smith (2004) for Lithobates pipiens tadpoles. Briefly, "activity" was defined as a constant movement across the aquarium, while "inactivity" meant that the animal remained motionless on the bottom or passively floating.

\subsection{Determination of the in situ heart rate}

Tadpoles (Controls and LAS groups) were euthanized by cranial concussion (CONCEA, 2013) to avoid side effects from anesthesics on the cardiac function. Body mass $(\mathrm{Wb}-\mathrm{g}$ ) of control and LAS-exposed tadpoles were determined. Thereafter, the in situ heart rate $\left(f_{\mathrm{H}}\right)$ was determined in bullfrog tadpoles placed in water-filled holding Petri dishes. A continuous flow of aerated physiological solution at 25 $\left( \pm 1{ }^{\circ} \mathrm{C}\right.$ ) was maintained throughout the chamber. The coelomic cavity was surgically opened in a caudal-cranial direction to expose the pericardium. In order to determine the heart rate, four animals of each treatment (CT and LAS) were randomly taken from each of the three replicated aquaria $(\mathrm{N}=12)$. These same animals were used later to prepare the ventricle strips.

The heart rate was determined by visual counting and expressed as beats per minute $(\mathrm{bpm})$. This procedure avoids the stress-induced adrenergic effects due to the in vivo implantation of subcutaneous ECG electrodes (Burggren et al., 1983; Feder, 1983; Wassersug et al., 1981), and provides direct data of the "basal" heart rate of the tadpoles (Costa et al., 2008; Dal-Medico et al., 2014).

\subsection{Determination of the relative ventricular mass}

After determining the heart frequency, the heart was dissected and the ventricle was carefully separated. The ventricles (6 from each experimental group, 2 from each aquarium) were weighed $(\mathrm{Wv}-\mathrm{g})$, and the ventricular mass was expressed as a percentage of body mass (relative ventricular mass, $\mathrm{RVM}-\%$ of $\mathrm{Wb}$ ).

\subsection{In vitro experiments}

Ventricle strips $(\mathrm{N}=12$; diameter $\sim 1.1 \mathrm{~mm}$; mass $=$ $2.2 \pm 0.13 \mathrm{mg}$; length $=2.2 \pm 1.4 \mathrm{~mm}-$ mean $\pm \mathrm{SE}$ ) from each experimental group were made for isometric contraction recordings, following the procedures described by Costa et al. (2008). The ventricle strips were transferred to a $30 \mathrm{~mL}$ thermostated cuvette $\left(25 \pm 1{ }^{\circ} \mathrm{C}\right)$ containing physiological solution proper to amphibians (in $\mathrm{mM}$ ): 115 $\mathrm{NaCl}, 5 \mathrm{KCl}, 30 \mathrm{NaHCO}_{3}, 0.94 \mathrm{MgSO}_{4}, 2.5 \mathrm{CaCl}_{2}$, and 5 glucose. This solution was bubbled throughout the whole experiment with a $2 \%$ carbogenic gas mixture $(\mathrm{pH} 7.5 \pm 0.1)$. Preparations were suspended with surgical silk, so that one side was attached to an isometric force transducer (Letica Corporation, USA) and the other end was tied around a platinum electrode. This electrode was placed within the cuvette and connected to a stimulator (AVS100D; Solução Integrada Ltda., Brazil). This stimulator was responsible for sending electrical square pulses (duration of $8 \mathrm{~ms}$ ) and for maintaining the voltage $50 \%$ above the threshold. This provides a security margin and assures the maximum stimulation throughout the experiment. Preparations were stretched to obtain the maximum relative length-twitch tension. Finally, the strips were left to stabilize during $40 \mathrm{~min}$ at $0.2 \mathrm{~Hz}(12 \mathrm{bpm})$ before each protocol (see below).

After the stabilization period, the contraction force ( $\mathrm{CF}-\mathrm{mN} \mathrm{mm}^{-2}$ ) was measured at the sub-physiological stimulation frequency of $0.2 \mathrm{~Hz}$ for $40 \mathrm{~min}$. Then, the stimulation frequency was stepwisely increased to verify the maximum stimulation frequency $\left(f_{\max }-\mathrm{bpm}\right)$ at which ventricle strips from each experimental group could still contract regularly. These measurements can be used as a comparative parameter with the heart rate observed in situ $\left(f_{\mathrm{H}}-\mathrm{bpm}\right)$.

\subsection{Heart histological analysis}

The hearts from each experimental group $(\mathrm{N}=6)$ were dissected and fixed in Metacarn solution (60\% methanol, 30\% chloroform, $10 \%$ acetic acid) at $4{ }^{\circ} \mathrm{C}$ for $3 \mathrm{~h}$. Then, the samples were subjected to a serial dehydration process and embedded in historesin (Leica-Historesin embedding kit, Leica Microsystems, Wetzlar, Germany). Sections of $2 \mu \mathrm{m}$ were obtained using a RM 2265 microtome (Leica, Switzerland). For histological analyses, sections were stained with hematoxylin-eosin and analyzed with a microscope (Leica DM4000 B) equipped with an image capturing system (Leica DFC 280). For the quantification of the nuclear size, we analyzed ten nucleus per section and 20 sections per animal. For the myocyte diameter, we analyzed 10 diameters per section and 20 histological heart sections per animal. All analyses were made using the software Image Pro Plus 6.0.

\subsubsection{Statistical analysis}

Results of cardiac performance are presented as means \pm S.E. The Kolmogorov and Smirnov method was adopted to verify the normality of the samples and the F-test was used for homogeneity of variances. For comparisons between the groups, the Student's t -test was used. (GraphPad Instat version 3.00, GraphPad Software, USA). Differences between means at a $5 \%(P<0.05)$ were considered statistically significant. Histological data were analyzed using R software version 3.2.0 (R Core Team. 2014). The myocyte diameter and nuclear volume (response variables) were tested against the exposure to LAS (predictor). These data were square-root transformed to meet the assumptions of homogeneity of variance and normality. Finally, we ran a separate onesample $t$-test to analyze the effect of the LAS treatment at each response variable.

\section{Results}

No tadpole deaths were observed during the exposure to any experimental groups (CT or LAS). However, the activity level of tadpoles (AL - \% of animals in each repetition) of the LAS group was reduced ( $9 \%$ of animals) $(P<0.05)$ when compared to the CT ( $23 \%$ of animals), and this behavior was accompanied by a decrease $(P<0.05)$ in the heart frequency $\left(f_{\mathrm{H}}-\mathrm{bpm}\right)$ (bradycardia) in the LAS group $(\mathrm{P}<0.05-$ $24 \%$ ) (Table 1). In contrast, the relative ventricular mass (RVM - \% of body mass) of the LAS group was highly increased (80\%) in relation to the CT (Fig. 1).

This increase in RVM was a result of a hypertrophy of the cardiac muscle, as corroborated by the enlargement of the nuclear measures (Fig. 2) and the increase in the myocyte diameters (Fig. 1).

Table 1

Activity level (AL; $N=36$ ), maximum stimulation frequency in which the ventricle strips still contract regularly in vitro $\left(f_{\max }-\mathrm{bpm} ; \mathrm{N}=12\right)$ and the heart frequency registred in loco $\left(f_{\mathrm{H}}-\mathrm{bpm} ; \mathrm{N}=12\right)$ for the control group (CT; $\left.\mathrm{N}=12\right)$ and linear alkylbenzene sulfonate (LAS) exposed group for $96 \mathrm{~h}(\mathrm{~N}=12)$ of Lithobates catesbeianus tadpoles. Means \pm S.E.

\begin{tabular}{lll}
\hline & CT & LAS \\
\hline $\boldsymbol{A L}(\%$ n) & $21.0 \pm 2.8$ & $9.0 \pm 2.8^{*}$ \\
$f_{\mathrm{H}}(\mathrm{bpm})$ & $72 \pm 4^{\dagger}$ & $62 \pm 4^{*}$ \\
Fmax $(b p m)$ & $108.0 \pm 0.2$ & $103.2 \pm 0.4$ \\
\hline
\end{tabular}

The asterisks "**" denote a significant difference $(P<0.05)$ between the values obtained for each experimental group (CT or LAS) in the same experimental protocol (AL, $f_{\max }$ or $f_{\mathrm{H}}$ ), while $\boldsymbol{\dagger}$ indicates significant difference $(P<0.05)$ between $f_{\max }$ or $f_{\mathrm{H}}$ in the same experimental group $(P>0.05)$. 


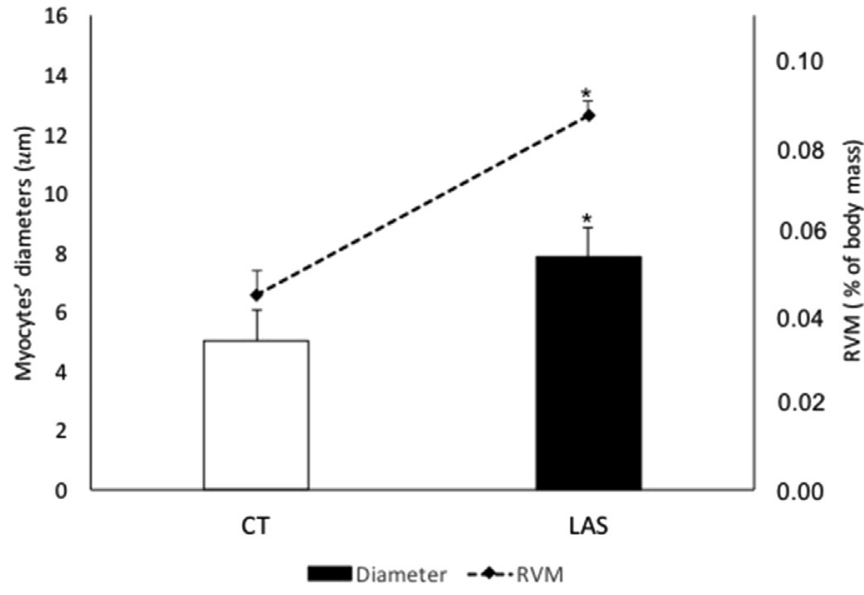

Fig. 1. Myocyte diameters and relative ventricular mass of Lithobates catesbeianus tadpoles from the control group ( $\mathrm{CT} ; \mathrm{N}=6$ ) and the group exposed to $0.5 \mathrm{mg} \mathrm{L}^{-1}$ of linear alkylbenzene sulfonate (LAS; $\mathrm{N}=6$ ) for $96 \mathrm{~h}$. The asterisks "*" above the vertical bars denotes a significant difference $(P<0.05)$ between LAS and CT for the same parameter. Results are presented as Means \pm S.E.
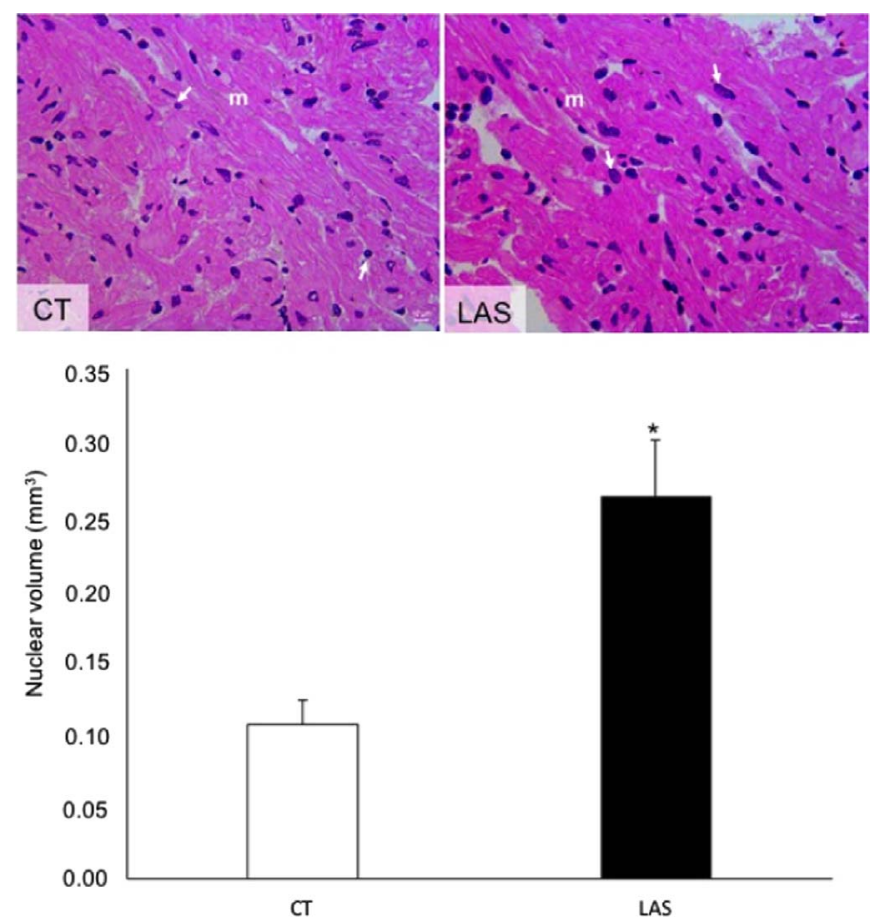

Fig. 2. Histological section of ventricle of Lithobates catesbeianus tadpoles from control group (CT; $\mathrm{N}=6$ ) and the group exposed to $0.5 \mathrm{mg} \mathrm{L}^{-1}$ of linear alkylbenzene sulfonate (LAS; $\mathrm{N}=6$ ) for $96 \mathrm{~h}$ stained with Hematoxilin-Eosin. In the LAS group (LAS), the myocyte diameter $(\mathrm{m})$ and the nuclear volume (arrow) are increased. The asterisks "*" above the vertical bars denote a significant difference $(P<0.05)$ between LAS and CT. Results are presented as Means \pm S.E.

In vitro studies demonstrated that LAS results in an increase from $63 \%$ to $78 \%(P<0.05)$ in ventricular contraction force (CF $-\mathrm{mN} \mathrm{mm}^{-2}$ ) when stimulated at $0.2 \mathrm{~Hz}$ in relation to the CT, irrespective of the stimulation period (Fig. 3), which may be correlated to the increase in RVM.

Inversely, the time to peak tension (TPT - ms) was decreased $(P<0.05)$ in the LAS group during the same period (varying from $12 \%$ to $18 \%$ ), which indicates an acceleration of the contractile dynamics in the ventricles of animals exposed to LAS (Fig. 4A). Nevertheless, the time to half relaxation (THR- ms), remained unchanged $(P>0.05)$ in the same period (Fig. 4B).

In Table 1 , the maximum stimulation frequency $\left(f_{\max }-\mathrm{bpm}\right)$ can be

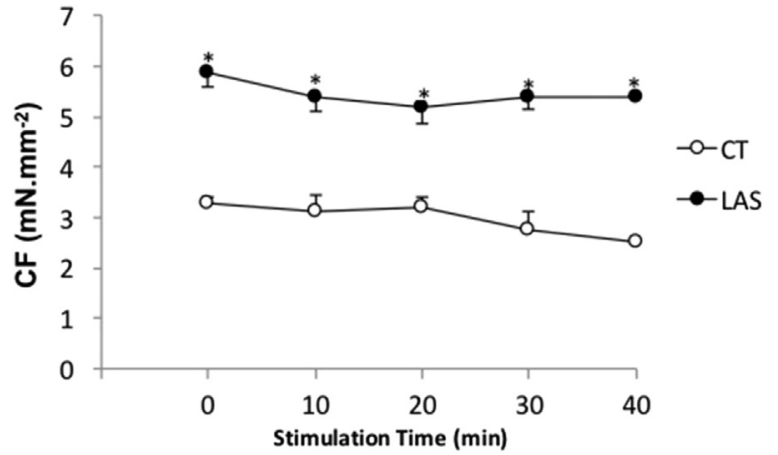

Fig. 3. Twitch force $\left(\mathrm{CF}-\mathrm{mN} \mathrm{mm}{ }^{-2}\right)$ developed by ventricle strips of Lithobates catesbeianus tadpoles from the control group ( $\mathrm{CT} ; \mathrm{N}=12$ ) and the group exposed to $0.5 \mathrm{mg} \mathrm{L}^{-1}$ of linear alkylbenzene sulfonate (LAS; $\mathrm{N}=12$ ) for $96 \mathrm{~h}$ under a stimulation pacing frequency of $0.2 \mathrm{~Hz}$ during $40 \mathrm{~min}$. The asterisks "*" above the vertical bars denotes a significant difference $(P<0.05)$ between LAS and CT. Results are presented as Means \pm S.E.
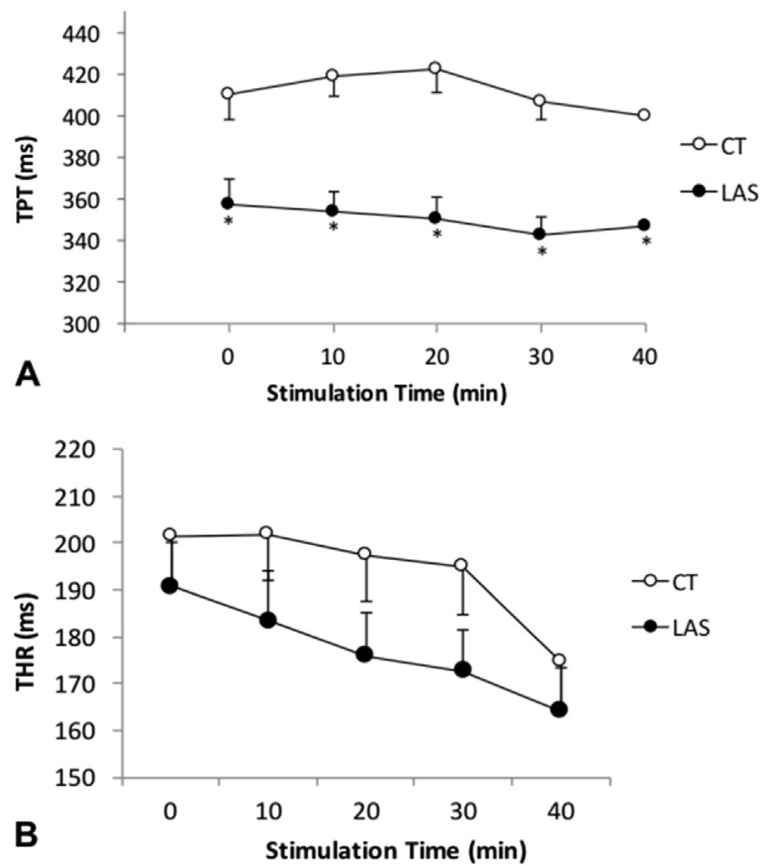

Fig. 4. Time to peak tension (TPT - ms; A) and time to half relaxation (THR - ms, B) developed by ventricle strips of Lithobates catesbeianus tadpoles from control group (CT; N = 12) and the group exposed to $0.5 \mathrm{mg} \mathrm{L}^{-1}$ of linear alkylbenzene sulfonate (LAS; $\mathrm{N}=$ 12) for $96 \mathrm{~h}$ under a stimulation pacing frequency of $0.2 \mathrm{~Hz}$ during $40 \mathrm{~min}$. Notice the different scales for A and B. The asterisks "*" above the vertical bars of panel A denotes a significant difference $(P<0.05)$ between LAS and CT. No significant differences $(P>0.05)$ were observed between the values obtained for the CT and LAS groups for THR. Results are presented as Means \pm S.E.

observed at which ventricle strips from each experimental group could still contract regularly after stepwise increases in the stimulation frequency when compared with the $f_{\mathrm{H}}(\mathrm{bpm})$ registred in situ. The $f_{\max }$ of the ventricle strips from CT and LAS groups were not differing from each other $(P>0.05)$. Notwithstanding, they were both much higher, indicating that in vivo the hearts from both groups still present a secure margin until reaching their maximum contractile capacity.

\section{Discussion}

Cardiac function has long been recognized as a potent bioindicator of toxicity in organisms exposed to pollutants and other toxicants (Lefrak et al., 1973; Kang, 2001). However, a detailed examination of cardiac biomarkers as a tool for environmental impact assessment has 
only been undertaken recently (Costa et al., 2008, 2015; Dal-Medico et al., 2014; Rissoli et al., 2016; Salla et al., 2016).

When exposed to adverse conditions, animals can either present escaping behaviors or activate physiological adjustments as an attempt to stabilize the organism (Salla et al., 2015). Therefore, animals may perform physiological adjustments, notably in the cardiac performance (Costa et al., 2008). Indeed, the exposure to LAS for $96 \mathrm{~h}$ has led to a decrease in the bullfrogs' activity level (AL). Bullfrog tadpoles exposed to methyl parathion and cadmium showed decreased of activity level (Dal-Medico et al., 2014; Costa el al, 2015), in accordance to observed in this study. The decrease of activity levels might be related to alterations in the cholinesterase activity (Araújo et al., 2007). According to these authors, cholinesterases (AChE) are widely used as biological biomarkers because their levels are reduced in response to exposure to xenobiotics. Once acetylcholine is not completely hydrolyzed, this process leads to hyperactivity of the cholinergic system. Therefore, the reduction in the tadpoles' activity level in response to LAS exposure is probably due to the fact that this xenobiotic inhibits acetylcholinesterase's (AChE) activity in the motor end-plate of the skeletal muscle fiber, impairing tadpoles' swimming performance. Similar results have been observed in bullfrog tadpoles in response to the exposure to other lipophilic contaminants, such as methyl parathion (Costa et al., 2015) and endosulfan (Denoël et al., 2013). In addition, studies have demonstrated a decrease in the swimming activity in response to the inhibition of AChE in some fish species (Brewer et al., 2001; Rao et al., 2005; Ballesteros et al., 2009). This effect of overstimulation of the cholinergic system was also observed in the heart of bullfrog tadpoles in this study, as corroborated by the bradycardia observed in situ. In agreement with these results, reductions in heart chronotropism have already been described for bullfrog tadpoles exposed to cadmium (Dal-Medico et al., 2014).

Given these results, it is important to consider that the capacity of the cardiac muscle to ensure the pumping performance under distinct physiological conditions is one of the most relevant features that enables vertebrates to survive under adverse conditions (Driedzic and Gesser, 1994). This ability results from the efficient maintenance of cardiac output through adjustments between the systolic volume and heart rate (Lillywhite et al., 1999; Withers and Hillman, 2001).

Thus, in response to the reduced AL and the bradycardia caused by LAS for $96 \mathrm{~h}$, one of the alternatives to maintain the cardiac output would be through a rise in the systolic volume at each beating cycle. In fact, the RVM increased in the exposed group. As a usual result of a hypertrophy of the myocytes, this increase in the RVM results in a larger volume of blood pumped, ensuring the maintenance of the blood supply to the animal, also aiding the detoxification. Indeed, in ectothermic vertebrates, a very common and rapid physiological adjustment to increase the systolic volume is the cardiac hypertrophy. Cardiac hypertrophic responses have already been reported as a mechanism that increases the cardiac performance in several situations, such as post-prandial stages in snakes (Andersen et al., 2005), and also after the exposure to several xenobiotics in amphibians (Calore et al., 2007; Salla et al., 2016).

These results were corroborated by the histological and the in vitro analyses, which demonstrated that intracellular effects promote cardiac physiological adjustments to the maintenance of homeostasis. At intracellular levels, the increase of nuclear sizes observed in response to LAS can be indicative of higher synthetic activity within the cell. Molecularly, it is known that nuclear size is an indirect measure of protein synthesis of the cell, which occurs essentially by an increase in nuclear activity with genomic expression and protein synthesis (Hellman and Petersson, 1960; Roberts et al., 1982). Thus, with the increase in nuclear activity, exposure to LAS can lead to a higher production of contractile proteins and consequently the myocyte diameter, resulting in the cardiac hypertrophy.

According to Kang (2001) and Molkentin et al. (1998), cell hypertrophy is considered an early protective mechanism in response to exposure to pollutants. The heart hypertrophy is often related to the increase in myocyte calcium concentrations, which may stimulate the expression of several transcription factors (Molkentin, 1998), raising protein synthesis and therefore increasing cell size (Kang, 2001). Despite the fact that the first reports of nuclear enlargement as a marker for myocyte hypertrophy were described in rats (Gerdes et al., 1994), this study is the first one to observe this response in amphibians.

The stroke volume is determined by the twitch force developed by the cardiac myocytes on a beat-to-beat basis (Salla et al., 2015), which depends mainly on the complex adjustment of intracellular calcium $\left(\left[\mathrm{Ca}^{2+}\right]_{\mathrm{i}}\right)$ homeostasis (Bers, 2001). The fluctuation of the intracellular calcium levels, which occurs in a coordinated way, largely determines the magnitude and duration of the cardiac muscle contraction (Rocha et al., 2007). In particular, the calcium transporting proteins responsible for the influx of calcium into the myocytes of amphibians are the $\mathrm{Na}^{+} / \mathrm{Ca}^{2}+$ (NCX) exchanger, working in its reverse form (Bers et al., 1988; Kawata, 1979; Luttgau and Niedergerke, 1958; Monteiro et al., 2016) and the L-type $\mathrm{Ca}^{2+}$ channel (Bers et al., 1988; Mikami et al., 1989; Tibbits et al., 1991; Romanin et al., 1992; Nakai et al., 1997). In this context, as a consequence of the cardiac hypertrophy, an increase in CF was observed in response to LAS, increasing the stroke volume and then leading to a readjustment of the cardiac output, which was impaired by the bradycardia. An increase in the contractile proteins and/or a higher expression of the calcium transporting proteins (NCX/ L-type channels) is directly related to the increase in the force of contraction. In addition, it has been reported that LAS induces an increase in intracellular $\mathrm{Ca}^{2+}$ concentration in cultured epithelial cells from Xenopus laevis kidney (Bjerregaard et al., 2001). Similar surfactants (POEA) also caused alterations in cellular membrane permeability, altering intracellular $\mathrm{Ca}^{2+}$ balance in Xenopus laevis (Hedberg and Wallin, 2010). This evidence reinforces our hypothesis that LAS alters intracellular calcium concentration and, consequently, can directly affect the heart function of bullfrog tadpoles. Similar results showing increased cardiac inotropism have already been reported in response to other xenobiotics (Dal-Medico et al., 2014; Salla et al., 2016). These findings, associated with the acceleration of the contraction (TPT) indicate that LAS interferes in the mechanisms of calcium influx. In contrast, LAS does not alter the mechanisms of efflux of calcium as the THR did not change. Altogether, these results point to the use of cardiac biomarkers at different levels (e.g., cellular, morphological and physiological) as early and sensitive biomarkers to evaluate effects of xenobiotics in tadpoles.

\section{Conclusion}

In conclusion, tadpoles exposed to a LAS concentration, which is considered environmentally safe, in fact promotes alterations in tadpoles' activities and in the heart at different levels (e.g. cellular, morphological, physiological and individual). These alterations in cardiac morphology and physiology can impair the fitness of tadpoles by diverting important energy sources, which may be lacking in other biological processes such as metamorphosis and the rapid response of escape from predators, among others. Consequently, it is imperative that the Brazilian Environmental Agency (CONAMA) revise the LAS concentrations considered safe.

\section{Acknowledgements}

The authors are also very grateful to R. L. Jacob (Vesuvius) and D. B. Provete for having conducted a careful revision of the English.

\section{Ethics}

The experiments were approved by the University's Ethics Committee (Protocol\#022/2010), which follows Brazilian regulating laws. 


\section{Conflicts of interest}

None.

\section{Funding}

The authors are thankful to the Brazilian Institute of Comparative Physiology (financial support to MJC, CNPq 573921/2008-3 and FAPESP 08/57712-4) and to CNPq for the fellowship to NPG (Proc. \# 165801/2013-1). FAPESP provided post-doctoral fellowship to LFB (2014/00946-4). LFB was also supported by a CAPES-PNPD postdoc fellowship during the final preparation of this manuscript. $\mathrm{CO}$ received a grant (305081/2015-2) from CNPq.

\section{References}

Abdalla, F.C., Martins, L.P.A., Silva-Zacarin, E.C.M., Rizzi, G.M., Costa, M.J., Salla, R.F., Kalinin, A.L., Monteiro, D.A., 2013. The impact of cadmium chloride on the gonadal morphology of the North American bullfrog tadpoles, Lithobates catesbeianus (Shaw, 1802). Fresenius Environ. Bull 22.

Andersen, J.B., Rourke, B.C., Caiozzo, V.J., Bennett, A.F., Hicks, J.W., 2005. Physiology: postprandial cardiac hypertrophy in pythons. Nature 434, 37-38.

Araújo, A.J., de, Lima, J.S., de, Moreira, J.C., Jacob, S., do, C., Soares, M., de, O., Monteiro, M.C.M., Amaral, A.M., do, Kubota, A., Meyer, A., Cosenza, C.A.N., Neves, C., das, Markowitz, S., 2007. Exposição múltipla a agrotóxicos e efeitos à saúde: estudo transversal em amostra de 102 trabalhadores rurais, Nova Friburgo, RJ. Cien Saude Colet. 12, 115-130. http://dx.doi.org/10.1590/S1413-81232007000100015.

ASTM, 2014. Standard guide for conducting acute toxicity tests on test materials with fishes, macroinvertebrates, and amphibians. Am. Soc. Test. Mater. ASTM Stand. http://dx.doi.org/10.1520/E0729-96R14.

Ballesteros, M.L., Durando, P.E., Nores, M.L., Díaz, M.P., Bistoni, M.A., Wunderlin, D.A., 2009. Endosulfan induces changes in spontaneous swimming activity and acetylcholinesterase activity of Jenynsia multidentata (Anablepidae, Cyprinodontiformes). Environ. Pollut. 157, 1573-1580. http://dx.doi.org/10.1016/j.envpol.2009.01.001.

Berger, L., Roberts, A.A., Voyles, J., Longcore, J.E., Murray, K.A., Skerratt, L.F., 2016. History and recent progress on chytridiomycosis in amphibians. Fungal Ecol. 19, 89-99. http://dx.doi.org/10.1016/j.funeco.2015.09.007.

Bers, D.M., 2001. Excitation-contraction coupling and cardiac contractile corce, optical mapping of cardiac excitation and arrhythmia. 〈http://dx.doi.org/10.1007/978-94 010-0658-3>.

Bers, D.M., Christenses, D.M., Nguyen, T.X., 1988. Can Ca entry via Na- Ca exchange directly activate cardiac muscle contraction? J. Mol. Cell. Cardiol. 20, 405-414.

Bjerregaard, H.F., Stærmose, S., Vang, J., 2001. Effect of linear alkylbenzene sulfonate (LAS) on ion transport and intracellular calcium in kidney distal epithelial cells ( A6) Toxicol. In vitro 15, 531-537.

Blaustein, A.R., Hoffman, P.D., Hokit, D.G., Kiesecker, J.M., Walls, S.C., Hays, J.B., 1994. UV repair and resistance to solar UV-B in amphibian eggs: a link to population declines? Proc. Natl. Acad. Sci. USA 91, 1791-1795.

Blaustein, A.R., Han, B.A., Relyea, R.A., Johnson, P.T.J., Buck, J.C., Gervasi, S.S., Kats, L.B., 2011. The complexity of amphibian population declines: understanding the role of cofactors in driving amphibian losses. Ann. N.Y. Acad. Sci. 1223 (1), 108-119.

Brasil, 2014. Ministério do Desenvolvimento, Indústria e Comércio Exterior. Relatório 4Químicos com Base em Fontes Renováveis. Rio de Janeiro, p. 118.

Brewer, S.K., Little, E.E., DeLonay, A.J., Beauvais, S.L., Jones, S.B., Ellersieck, M.R., 2001. Behavioral dysfunctions correlate to altered physiology in rainbow trout (Oncorynchus mykiss) exposed to cholinesterase-inhibiting chemicals. Arch. Environ. Contam. Toxicol. 40, 70-76. http://dx.doi.org/10.1007/s002440010149.

Bueno-Guimarães, H.M., Ferreira, C.M., Garcia, M.L.B., Saldiva, P.H.N., 2001. Tadpole epithelium test: potential use of histopathologic epithelial changes to evaluate aquatic pollution. Bull. Environ. Contam. Toxicol. 67, 0202e0209. http://dx.doi.org/ 10.1007/s00128-001-0111-1.

Burggren, W.W., Feder, M.E., Pinder, A.W., 1983. Temperature and the balance between aerial and aquatic respiration in larvae of Rana berlandieri and Rana catesbeiana. Physiol. Zool. 56, 263-273.

Calore, E.E., Perez, N.M., Herman, M.M., 2007. Morphometric studies of cardiac myocytes of rats chronically treated with an organophosphate. Ecotoxicol. Environ. Saf. 66 (3), 447-450. http://dx.doi.org/10.1016/j.ecoenv.2006.04.001. PMid:16797706.

Carvalho, C.S., Utsunomiya, H.S.M., Pasquoto, T., Lima, R., Costa, M.J., Fernandes, M.N., 2017. Blood cell responses and metallothionein in the liver, kidney and muscles of bullfrog tadpoles, Lithobates catesbeianus, following exposure to different metals. Environ. Pollut. 221, 445-452. http://dx.doi.org/10.1016/j.envpol.2016.12.012.

Coelho, K.S., Rocha, O., 2010. Assessment of the potential toxicity of a linear alkylbenzene sulfonate (LAS) to freshwater animal life by means of cladoceran bioassays. Ecotoxicology 19 (4), 812-818.

Collins, J.P., 2010. Amphibian decline and extinction: what we know and what we need to learn. Dis. Aquat. Organ. 92, 93-99. http://dx.doi.org/10.3354/dao02307.

Collins, J.P., Storfer, A., 2003. Global amphibian declines: sorting the hypotheses. Divers. Distrib. 9, 89-98. http://dx.doi.org/10.1046/j.1472-4642.2003.00012.x.

CONCEA, 2013. Ministério da Ciência e Tecnologia, Diretrizes da prática de Eutanásia do. Cons. Nac. Control Exp. Anim. Resoluç. Norm. Pag. 1, 54.

CONAMA, 2011. Resolução CONAMA 430/2011. Diário União 8. http://dx.doi.org/10. 1073/pnas.0703993104.

Costa, M.J., Monteiro, D.A., Oliveira-Neto, A.L., Rantin, F.T., Kalinin, A.L., 2008 Oxidative stress biomarkers and heart function in bullfrog tadpoles exposed to Roundup Original. Ecotoxicology 17, 153-163. http://dx.doi.org/10.1007/s10646 007-0178-5.

Costa, M.J., Ribeiro, L.R., Salla, R.F., Gamero, F.U., Alves, L.M.L.M., Silva-Zacarin, E.C.M., 2015. Effects of the organophosphorus pesticide Folisuper 600 (methyl parathion) on the heart function of bullfrog tadpoles, Lithobates catesbeianus (Shaw, 1802). Brazilian J. Biol. 75. http://dx.doi.org/10.1590/1519-6984.08314.

Dal-Medico, S.E., Rissoli, R.Z., Gamero, F.U., Victório, J.A., Salla, R.F., Abdalla, F.C., Silva-Zacarin, E.C.M., Carvalho, C.S., Costa, M.J., 2014. Negative impact of a cadmium concentration considered environmentally safe in Brazil on the cardiac performance of bullfrog tadpoles. Ecotoxicol. Environ. Saf. 104. http://dx.doi.org/10 1016/j.ecoenv.2014.03.003.

Denoël, M., Libon, S., Kestemont, P., Brasseur, C., Focant, J.F., De Pauw, E., 2013. Effects of a sublethal pesticide exposure on locomotor behavior: a video-tracking analysis in larval amphibians. Chemosphere 90, 945-951. http://dx.doi.org/10.1016/j. chemosphere.2012.06.037.

Driedzic, W.R., Gesser, H., 1994. Energy metabolism and contractility in ectothermic vertebrate hearts: hypoxia, acidosis, and low temperature. Physiol. Rev. 74, 221-258.

Feder, M.E., 1983. Responses to acute aquatic hypoxia in larvae of the frog Rana berlandieri. J. Exp. Biol. 104, 79-95.

Fraker, S.L., Smith, G.R., 2004. Direct and interactive effects of ecologically relevant concentrations of organic wastewater contaminants on Rana pipiens tadpoles. Environ. Toxicol. 19, 250-256. http://dx.doi.org/10.1002/tox.20017.

Gerdes, A.M., Kellerman, S.E., Malec, K.B., Schocken, D.D., 1994. Transverse shape characteristics of cardiac myocytes from rats and humans. Cardioscience 5, 31-36.

Gosner, K.L., 1960. A simplified table for staging anuran embryos larvae with notes on identification. Herpetologica 16, 183-190. http://dx.doi.org/10.2307/3890061.

Heatwole, H., Wilkinson, J.W., 2009. Amphibian Biology Volume 8- Amphibian Decline: Diseases, Parasites, Maladies and Pollution. Baulkham Hill: Surrey Beatty \& Sons. 2009 (327p).

Hedberg, D., Wallin, M., 2010. Effects of Roundup and glyphosate formulations on in tracellular transport, microtubules and actin filaments in Xenopus laevis melanophores. Toxicol. In Vitr. 24 (3), 795-802. http://dx.doi.org/10.1016/j.tiv.2009.12. 020.

Hellman, B., Petersson, B., 1960. The activity of the islet B Cells as indicated by the nuclear and nucleolar size in the american obese-hyperglycemic mice. Acta Pathol. Microbiol. Immunol. Scand. 50, 291-296.

Hof, C., Araújo, M.B., Jetz, W., Rahbek, C., 2011. Additive threats from pathogens, climate and land-use change for global amphibian diversity. Nature 418, 516-521. http://dx.doi.org/10.1038/nature10650.

Ivankovi, Ć.T., Hrenović, J., 2010. Review: surfactants in the environment. Arh. Hig. Rada Toksikol. 2010 (61), 95-110.

Kang, Y.J., 2001. Molecular and cellular mechanisms of cardiotoxicity. Environ. Health Perspect. 109, 27-34. http://dx.doi.org/10.1007/s12012-007-0005-5.

Kawata, H., 1979. Contractility of the frog ventricular myocardium in sodium-free lithium solution. Jpn. J. Physiol. 29, 609-625. http://dx.doi.org/10.2170/jiphysiol.29.609.

Kikuchi, M., Wakabayashi, M., Kojima, H., Yoshida, T., 1980. Bioaccumulation profiles of 35S-labelled sodium alkylpoly(oxyethylene) sulfates in carp (Cyprinus carpio). Water Res. 14, 1541-1548. http://dx.doi.org/10.1016/0043-1354(80)90022-6.

Kulkarni, R.D., Goddard, E.D., 1980. Potential of excised frog skin by surfactants. Adv. Chem. 26, 445-459.

Kumar, M., Trivedi, S.P., Misra, A., Sharma, S., 2007. Histopathological changes in testis of the freshwater fish, Heteropneustes fossilis (Bloch) exposed to linear alkyl benzene sulphonate (LAS). J. Environ. Biol. 28, 679-684.

Lefrak, E.A., Pitha, J., Rosenheim, S., Gottlieb, J.A., 1973. A clinicopathologic analysis of adriamycin cardiotoxicity. Cancer 32, 302-314. http://dx.doi.org/10.1002/10970142(197308) 32 .

Lillywhite, H.B., Zippel, K.C., Farrell, A.P., 1999. Resting and maximal heart rates in ectothermic vertebrates. Comp. Biochem. Physiol. - A Mol. Integr. Physiol. 124, 369-382. http://dx.doi.org/10.1016/S1095-6433(99)00129-4.

Lüttgau, H.C., Niedergerke, R., 1958. The antagonism between Ca and Na ions on the frog's heart. J. Physiol. 143, 486-505.

McDiarmid, R.W., Altig, R., 1999. Tadpoles: The Biology of Anuran Larvae. Chicago University Press, Chicago, pp. 444.

Mikami, A., Imoto, K., Tanabe, T., Niidome, T., 1989. Primary structure and functional expression of the cardiac dihydropyridine-sensitive calcium channel. Nature 340, 230-233.

Molkentin, J.D., Lu, J.R., Antos, C.L., Markham, B., Richardson, J., Robbins, J., Grant, S.R., Olson, E.N., 1998. A calcineurin-dependent transcriptional pathway for cardiac hypertrophy. Cell 93, 215-228. http://dx.doi.org/10.1016/S0092-8674(00)81573-1.

Monteiro, D.A., Kalinin, A.L., Selistre-De-Araujo, H.S., Vasconcelos, E.S., Rantin, F.T., 2016. Alternagin-C (ALT-C), a disintegrin-like protein from Rhinocerophis alternatus snake venom promotes positive inotropism and chronotropism in fish heart. Toxicon 110, 1-11. http://dx.doi.org/10.1016/j.toxicon.2015.11.012.

Nakai, J., Ogura, T., Protasi, F., Franzini-Armstrong, C., Allen, P.D., Beam, K.G., Akai, J.U.N., Gura, T.A.O., Rotasi, F.E.P., Rmstrong, C.L.F.R., Llen, P.A.U.L.D.A., 1997. Functional nonequality of the cardiac and skeletal ryanodine receptors. Proc. Natl. Acad. Sci. USA 94, 1019-1022. http://dx.doi.org/10.1073/pnas.94.3.1019.

Penteado, J.C.P., El Seoud, O.A., Carvalho, L.R.F., 2006. Revisão, Alquilbenzeno Sulfonato Linear: Uma Abordagem Ambiental e Analítica. Quím. Nova, vol.29 no.5 São Paulo.

Priya, R., Uma, T., Saravanan, N., N, J.N., 2016. Efficacy of detergent on hepatocyte morphological changes in fish, tilapia mossambica. J. Entomol. Zool. Stud. 4, 655-658.

Rao, J.V., Begum, G., Pallela, R., Usman, P.K., Rao, R.N., 2005. Changes in behavior and 
brain acetylcholinesterase activity in mosquito fish, Gambusia affinis in response to the sub-lethal exposure to chlorpyrifos. Int. J. Environ. Res. Public Health 2, 478-483. http://dx.doi.org/10.3390/ijerph2005030013.

Rissoli, R.Z., Abdalla, F.C., Costa, M.J., Rantin, F.T., McKenzie, D.J., Kalinin, A.L., 2016. Effects of glyphosate and the glyphosate based herbicides Roundup Original and Roundup Transorb on respiratory morphophysiology of bullfrog tadpoles. Chemosphere 156, 37-44. http://dx.doi.org/10.1016/j.chemosphere.2016.04.083.

Roberts, W.E., Mozsary, P.G., Klingler, E., 1982. Nuclear size as a cell-kinetic marker for osteoblast differentiation. Am. J. Anat. 165, 373-384. http://dx.doi.org/10.1002/ aja.1001650403.

Rocha, M.L., Rantin, F.T., Kalinin, A.L., 2007. Importance of the sarcoplasmic reticulum and adrenergic stimulation on the cardiac contractility of the neotropical teleost Synbranchus marmoratus under different thermal conditions. J. Comp. Physiol. B. 177, 713-721. http://dx.doi.org/10.1007/s00360-007-0166-3.

Roe, J.H., Hopkins, W.A., Jackson, B.P., 2005. Species- and stage-specific differences in trace element tissue concentrations in amphibians: implications for the disposal of coal-combustion wastes. Environ. Pollut. 136, 353-363. http://dx.doi.org/10.1016/j. envpol.2004.11.019.

Romanin, C., Karlssom, J.-O., Schindler, H., 1992. Activity of cardiac L-type Ca channels is sensitive to cytoplasmic calcium. Eur. J. Physiol. 421, 516-518.

Salla, R.F., Gamero, F.U., Ribeiro, L.R., Rizzi, G.M., Dal Medico, S.E., Rissoli, R.Z., Vieira, C.A., Silvazacarin, E.C.M., Leite, D.S., Abdalla, F.C., Toledo, L.F., Costa, M.J., 2015. Cardiac adaptations of bullfrog tadpoles in response to chytrid infection. J. Exp. Zool. Part A Ecol. Genet. Physiol. 323, 487-496. http://dx.doi.org/10.1002/jez.1945.

Salla, R.F., Gamero, F.U., Rissoli, R.Z., Dal-Medico, S.E., Castanho, L.M., Carvalho, C.D.S., Silva-Zacarin, E.C.M., Kalinin, A.L., Abdalla, F.C., Costa, M.J., 2016. Impact of an environmental relevant concentration of $17 \alpha$-ethinylestradiol on the cardiac function of bullfrog tadpoles. Chemosphere 144. http://dx.doi.org/10.1016/j.chemosphere. 2015.10.042.

Sparling, D.W., Linder, G., Bishop, C.A., 2000. In: Birg, W.J., Westerman, A.G.,
Spromberg, J.A. (Eds.), Ecotoxicology of Amphibians and Reptiles. SETAC Press, Cap XIVA. Pensacola, pp. 727-791.

Shi, Y.-B., 2000. Amphibian Meamorphosis. From Morphology to Molecular Biology. John Wiley \& Sons, New York.

Tibbits, G.F., Hove-Madsen, L., Bers, D.M., 1991. Calcium transport and the regulation of cardiac contractility in teleosts: a comparison with higher vertebrates. Can. J. Zool. 69, 2014-2019.

Tolls, J., Kloeppersams, P., Sijm, D., 1994. Surfactant bioconcentration - a critical-review. Chemosphere 29, 693-717. http://dx.doi.org/10.1016/0045-6535(94)90040-x.

Van Meter, R.J., Glinski, D.A., Hong, T., Cyterski, M., Henderson, W.M., Purucker, S.T., 2014. Estimating terrestrial amphibian pesticide body burden through dermal exposure. Environ. Pollut. 193, 262-268. http://dx.doi.org/10.1016/j.envpol.2014.07. 003.

Venhuis, S.H., Mehrvar, M., 2004. Health effects, environmental impacts, and photochemical degradation of selected surfactants in water. Int. J. Photoenergy 6 , 115-125. http://dx.doi.org/10.1155/S1110662×04000157.

Wake, D.B., Vredenburg, V.T., 2008. Are we in the midst of the sixth mass extinction? A view from the world of amphibians. Proc. Natl. Acad. Sci. USA 105, 11466-11473. http://dx.doi.org/10.1073/pnas.0801921105.

Wassersug, R.J., Paul, R.D., Feder, M.E., 1981. Cardio-respiratory synchrony in anuran larvae (Xenopus laevis, Pachymedusa dacnicolor, and Rana berlandieri). Comp. Biochem. Physiol. - Part A Physiol. 70, 329-334. http://dx.doi.org/10.1016/03009629(81)90186-9.

Withers, P.C., Hillman, S.S., 2001. Allometric and ecological relationships of ventricle and liver mass in anuran amphibians. Funct. Ecol. 15, 60-69. http://dx.doi.org/10.1046/ j.1365-2435.2001.00495.x.

Yu, S., Wages, M., Willming, M., Cobb, G.P., Maul, J.D., 2015. Joint effects of pesticides and ultraviolet-B radiation on amphibian larvae. Environ. Pollut. 207, 248-255. http://dx.doi.org/10.1016/j.envpol.2015.09.029. 